\title{
Source Municipal Management In Russia: The National Base Of The President And System Digitalization
}

\section{Fuente Gestión Municipal En Rusia: \\ La Base Nacional Del Presidente Y La Digitalización Del Sistema}

\author{
Lyudmila A. Kalinichenko* \\ Doctor of Sociology, Professor, Russian State Social University, Russia \\ Orcid: https://orcid.org/0000-0002-1756-5652
}

Olga A. Urzha

Doctor of Sociology, Professor at the Department of Management and Administration,

Russian State Social University, Russia

Orcid: https://orcid.org/0000-0001-6328-8898

Lyubov V. Adamskaya

Candidate of Sociological Sciences, Assistant professor at the Department of State and Municipal Administration, Financial University under the Government of the Russian Federation

Orcid: https://orcid.org/0000-0003-0754-2489

\section{Tatiana A. Evstratova}

Candidate of Sociological Sciences, Assistant professor at the Department of Management and Administration, Russian State Social University, The Russian Federation, Moscow

Orcid: https://orcid.org/0000-0002-8737-3218

\section{Natalia V. Medvedeva}

Candidate of Sociological Sciences, Assistant Professor at the Department of Management and Administration, Russian State Social University, The Russian Federation, Moscow Orcid: https://orcid.org/0000-0001-5265-4784

* Correspondence

Email: viktor2000spb@mail.ru
Citation:

Lyudmila A. Kalinichenko, Olga A. Urzha, Lyubov V. Adamskaya, Tatiana A. Evstratova, Natalia V. Medvedeva. (2021). Source Municipal Management In Russia: The National Base Of The President And System Digitalization. Propósitos y Representaciones, 9 (SPE3), e1164. Doi: http://dx.doi.org/10.20511/pyr2021.v9nSPE3.1164 


\begin{abstract}
The purpose of the study is the diagnosis of practice and the introduction of new legal norms and digital technologies of municipal administration; life quality improvement and sustainable socioeconomic development provision in all municipalities of vast Russia. The article analyzes the necessary changes in the Constitution of the Russian Federation (1993), which should ensure life quality increase and accelerated socio-economic development of municipalities. These include: the changes in the powers and functions of local governments; strengthening the responsibility of local administrations for social performance results. A search is underway for the optimal coordination of the functions and powers of federal, regional and municipal governments on a new constitutional basis. The scientific basis of municipal administration is being developed - the theory of municipal service as the managerial core of local self-government is proposed. The scientific methodology of the state and municipal services is correlated. New parameters of social responsibility of local government officials are defined. The possibilities of digital technologies are being studied to increase the effectiveness of municipal governance. The article proposes to conduct systemic digitalization of state and municipal government actively. New digital technologies are considered as a necessary scientific and informational basis to increase the effectiveness of local management. In the article, each of the proposed trends for municipal governance improvement is considered from the perspective of the possible interaction problem study between the authorities and citizens; the conflicts between authorities at various levels. They studied the danger of the destructive consequences of existing performance indicators, local management methods and technique conservation. They presented the perspectives of further research and officials and local administration efficiency and responsibility increase.
\end{abstract}

Keywords: municipal government; constitutional changes in local government powers; scientific base; system digitalization

\title{
Resumen
}

El propósito del estudio es el diagnóstico de la práctica y la introducción de nuevas normas legales y tecnologías digitales de la administración municipal; mejora de la calidad de vida y provisión de desarrollo socioeconómico sostenible en todos los municipios de la vasta Rusia. El artículo analiza los cambios necesarios en la Constitución de la Federación de Rusia (1993), que deberían garantizar el aumento de la calidad de vida y el desarrollo socioeconómico acelerado de los municipios. Estos incluyen: los cambios en los poderes y funciones de los gobiernos locales; fortalecer la responsabilidad de las administraciones locales por los resultados del desempeño social. Se está buscando la coordinación óptima de las funciones y competencias de los gobiernos federal, regional y municipal sobre una nueva base constitucional. Se está desarrollando la base científica de la administración municipal: se propone la teoría del servicio municipal como núcleo gerencial del autogobierno local. Se correlaciona la metodología científica de los servicios estatales y municipales. Se definen nuevos parámetros de responsabilidad social de los funcionarios del gobierno local. Se están estudiando las posibilidades de las tecnologías digitales para incrementar la eficacia de la gobernanza municipal. El artículo propone realizar una digitalización sistémica del gobierno estatal y municipal de forma activa. Las nuevas tecnologías digitales se consideran una base científica e informativa necesaria para incrementar la eficacia de la gestión local. En el artículo, cada una de las tendencias propuestas para la mejora de la gobernanza municipal es considerada desde la perspectiva del posible estudio del problema de interacción entre autoridades y ciudadanos; los conflictos entre autoridades a varios niveles. Estudiaron el peligro de las consecuencias destructivas de los indicadores de desempeño existentes, los métodos de manejo local y la conservación de técnicas. Presentaron las perspectivas de futuras investigaciones y el aumento de la eficiencia y la responsabilidad de los funcionarios y la administración local.

Palabras clave: Gobierno municipal; cambios constitucionales en los poderes del gobierno local; base científica; digitalización del Sistema 


\section{Introduction}

The task of citizen life and work effective organization in each region of Russia is important and difficult. How can they improve the quality of life and ensure sustainable economic development in all settlements throughout vast Russia, raise them to the level of a rich and developed Moscow? In fact, less than 5\% of Russian citizens in modern Russia own $90 \%$ of the national wealth produced by the whole nation. And this wealth is visibly concentrated in Moscow. According to the survey of the All-Russian Center for the Study of Public Opinion, conducted in October 2019, respondents answered as follows to the question: "Is there any national unity in the Russian Federation?": "More likely there is not" - 54\%, "Most likely there is" - 37\%. In 2015 and 2017, the positive assessment of unity among the population was $20 \%$ higher (WCIOM, 2019).

A comparison with the neighboring state, China, is logical. Back in 1988, it was one of the poorest countries in the world. The problems were compounded by a huge population. $88 \%$ of Chinese - hundreds of millions - lived below the poverty line, according to United Nations standards. They existed at $\$ 2$ per day (approximately 140 modern Russian rubles). In 2019, the rate of poor Chinese was only $0.7 \%$ of the population. Undoubtedly, the leadership of the People's Republic of China will soon complete the task: poverty will disappear. The secret to economic success and getting out of poverty: the country leadership and all levels of government understand the need to work in the "outback", in the poorest villages. The leader of the Chinese Communist Party, Xi Jinping, has been working at the most difficult peasant work since he was 16, sleeping on the floor and starving. And, at the same time, he walked 10 kilometers to get to the library and read books: "How steel was tempered" by N. Ostrovsky, "Warlords of the Great Patriotic War" by M. Gorky and others. The understanding of ordinary people hardships and practical technologies by the senior leader have helped to raise the Chinese "outback". Now, by the order of the leadership of the PRC Communist Party, officials are obliged to live in a peasant family in a village 2 days a month and help peasants to work in the fields.

The problems of inequality and injustice of remuneration for labor have not been solved for millennia in the world. Inequality escalated especially in the 21 st century; its painful perception by the population is exacerbated by the general informatization and global human community openness. The study of contemporary global socio-economic issues was carried out at the end of 2019 by the sociological group Edelman Trust Barometr, and was widely quoted at meetings of analysts in Davos. This study showed capitalism criticism increase around the world: $56 \%$ of respondents say that there is more harm to capitalism than good (Edelman Trust Barometr, 2019).

How they solve the problems of regional inequality and equalization of living standards in small settlements of the developed countries of the world?

Comparative cross-country analysis shows that in European countries and developed Asian countries, state power quite successfully solves the problems of regional inequality and equalization of living standards in small settlements (Hughes, 2019; Cuadrado-Ballesteros \& etc, 2020; Ngan, 2020; Obasa, 2019). On the American mainland, economically rich countries strengthen local government financially consistently (Nukpezah, 2019; Man \& Rosentraub, 1998). China has successfully implemented government policies to support remote and poor settlements (examples and technologies of actions by Chinese officials were given above) (Stockmann \& etc, 2011; Cao, 2014; Eberhardt, 2015).

In modern Russia, the situation is paradoxical: how could a country that was in the top ten countries of the world in terms of scientific-production and social indicators, with the best healthcare and education system in the world, become a country with a huge percentage of the poor and impoverished and catastrophic income inequality over the same 30 years? At the same time, Russia remains the richest country in terms of natural resources and gold and foreign exchange reserves. At the end of 2019, the All-Russian Center for the Study of Public Opinion analyzed what problems worried Russians most of all. The problem of inequality between people is in the first place, - $68 \%$ 
of Russians declared this problem; inequality is accompanied by income reduction problems - $63 \%$ of respondents; refusal to provide free medical care - $58 \%$, etc.

The World Bank is conducts research on the quality of public administration in various countries of the world systematically. Since the late 1990-ies the quality of public administration in Russia was rated as very low - according to the indicator of "taking into account the opinion of the population", Russian officials received 18 points out of 100 points.

The high-quality organization of citizens' life in the municipalities of all regions of Russia is the task of social justice restoration and overcoming the chasm of economic inequality.

In municipalities (villages, districts, cities), power is closest to a person - the main social goals of the modern Russian state should be decided there. In municipalities, the problems of economic inequality are real and the ulcers of social injustice are exposed. According to Russian statistics, over $75 \%$ of all housing is built in the largest metropolitan areas - villages die and disappear from the Russian map; $30 \%$ of residents of settlements and towns go to work in large cities.

The Russian regional policy of equalizing the living standards of Russians is focused on subsidies to the regions and shows low efficiency.

In practice, a dangerous situation develops in Russia:

- on the one hand, the population also understands the need for local self-government at the highest level of power, - the rights of local self-government are enshrined in the highest law of Russia - the 1993 Constitution of the Russian Federation;

- On the other hand, there are catastrophic gaps between the standard of living of Russian citizens in the capital center, in regional cities and in small settlements. Local governments are not yet able to manage and reduce these gaps effectively, to bring the standard of living of ordinary Russians in thousands of villages and small towns closer to the living standards of the 21 st century.

Improvement of local self-government efficiency in all settlements of Russia is a necessary condition to improve the quality of life of Russians.

The dangerous situation of socio-economic inequality and gaps in the quality of life of the population of the detached villages and major cities has been largely recognized by scientists, practical managers and is acutely worried by Russian citizens. The solution of issues related to the improvement of socio-economic relations at the municipal level has been the subject of a lot of research in various fields - financial, economic, legal, sociological, etc.

This article attempts to systematically approach the development of a new municipal government paradigm based on the general theory of unified public authority and the specific theory of state and municipal service. On the basis of the new management paradigm, they proposed changes in the constitutional powers and functions of local governments; development of modern scientific management technologies and the methods of systemic digitalization of municipalities.

\section{Methodology}

Local self-government is the population power in municipalities. The process of local authority implementation in practice is provided by municipal government. Municipal management is necessary and it must become effective. The effectiveness of municipal management is conditioned by the use of centuries-old practical experience and a modern management methodology development.

Studying the development of local self-government and municipal government methods, one can distinguish such theories as the theory of a free community (K.-O. Laband, G. Arens, F. Gerber, E. Meyer); the public theory of self-government (A. Gerber, D. Arens, E. Meyer, O. Laband, O. Ressler; in Russia: A.I. Vasilchikov and V.N. Leshkovi et al.); state management theory (R. 
Gneist, L. Stein; in Russia - N.I. Lazarevsky, A.D. Gradovsky, V.P. Bezobrazov); dualism theory of municipal government (N.I. Lazarevsky and B.N. Chicherin; economic theory (R. Mol, A.I. Vasilchikov); - political theory; legal theory (G. Jellinek, I.I. Evtikhiev and N.M. Korkunov) and other theories.

Modern Russian scientific schools of local self-government and municipal government are based on the theory of the unified public authority of Russia, with the distribution of powers by management level: local (primary), regional and federal (unifying). The theory of unified public authority is developed by many scientific schools, including the special sociological theory of public service social organization (Kalinichenko L.A., 2001).

The theory of municipal service was created as a specific part of the general theory of public authority. Municipal service is studied as the managerial core of local government (Kalinichenko L.A., 1998; Kalinichenko \& Adamskaya, 2018). The sociological theory of social engineering makes the contribution to the development of the management methodology (Urzha \& etc, 2018a, 2018b).

Systems Theory of Technologization (Ivanov, 1996; Urzha, 2019) and practical digital technologies of municipal management should become the necessary technological base to improve the efficiency of municipal management.

Modern sociology creates a holistic view of society and its problems. The most acute contemporary problem is socioeconomic inequality in society; this problem is acutely felt by people in municipalities. The methods of sociological analysis allow us to understand the causes and consequences of this problem existence for local self-government development. Sociological schools have studied the methods for overcoming inequality, from O. Comte, E. Durkheim to modern sociological and economic theories. The methodology of comparative intercountry analysis helps to identify the countries where the government is more successful for regional inequality problem solution and equalization of living standards in small settlements. Modern sociologists draw conclusions about the latest socio-economic methods of inequality overcoming in the poorest countries - the Nobel Prize is awarded for these scientific developments.

The theory of state and municipal service on the basis of the general theory of a unified public authority can provide increased efficiency and responsibility of municipal administration to the population and the state. But earlier this methodological approach was not used in managerial practice in Russia. This methodological approach requires the disclosure of method development results for the interaction of single public authority levels (federal, regional and local) in the process of population life quality improvement.

\section{Results}

\section{Creation of a scientific school of socially effective and responsible state and municipal service}

Scientific schools of local self-government and municipal government origin and development reveal the dichotomy of local self-government.

For a long time, the theories of local self-government and municipal government have been developed: free communities, social theory, state theory, economic theory; legal theory; socialist theory and others. The indicated theories studied and absolutized one of the essential features of local self-government - it could be a sign of economic activity, or they absolutized the legal aspect, or emphasized etymological features, etc.

The dualism theory of local self-government proves that neither of the previously mentioned theories reflects the diversity of the essential features of local self-government. The dualism of local self-government is manifested in the fact that, on the one hand, local self-government has developed independently and has a long history of development in Russia. This is the rural community "peace", this is the Cossack community and many other forms of local government. The independence of local self-government is recognized and guaranteed by the constitutions of many 
states of the world. The RF Constitution of 1993 confirms and protects the independence of local self-government in local issue resolution within its own powers.

On the other hand, it is the state that recognizes and guarantees local self-government. According to the Constitution of the Russian Federation of 1993, state power guarantees local government. This is consistent with the European Charter of Local Government. The Russian state has established that the local level of power is a subordinate and controlled by state power.

The centuries-old historical experience of local self-government in various countries suggests a continuous search for a balance between two dialectical opposites - local self-government and state centralism.

Modern local government dichotomously combines two principles: public self-government and power management. A number of theories substantiate the socio-state nature of the modern model of local self-government.

Local self-government bodies are the part of the general management system of Russia, they represent the primary level of government - local (or municipal).

The new management methodology, formed by the authors of this article, allows you to transform the governing bodies of all levels into a socially responsible and economically effective public law institution.

The administrative core of a single public authority is the state and municipal service.

The theory of state and municipal service has a single subject area - this is the professional managerial activity of the authorities as a social and public law institution (Kalinichenko L.A., 1998). Municipal service is largely integrated into the state mechanism; it performs the functions of national importance. The municipal service operates under state control. Performing functions in both state and municipal service are carried out by professionally trained employees as a permanent official activity.

There is a single social nature of state and municipal services - the need to solve social problems to improve the population life quality. The state and municipal service are united by uniform principles of organization and activity. These are public law institutions that are required to comply with the Constitution of the Russian Federation and other laws. The principle of professionalism, competence and responsibility of state and municipal employees is mandatory.

The theory of state and municipal service studies the state and municipal service as a professional managerial activity of social unified public authorities.

The constitutional amendments proposed by the RF President implement the current trend towards integration of state and municipal body powers in order to improve the life quality of Russian citizens. These are new social standards for public health preservation, family support, and decent life and work provision. Constitutional amendments should be enshrined in by-laws and in the procedural rules of state and municipal employee activity.

The main goal of the state and municipal services is the need to solve the socio-economic problems of life quality improvement, therefore, new uniform indicators of the social efficiency of state and municipal body activities should be approved.

There are differences in state and municipal services, respectively, the division of a single public authority at different levels. The tasks faced by public servants are larger and more complex. Municipal employees have different difficulties - they have daily work; they work face-to-face with the population; the problems faced by municipal employees are socially aggravated.

Municipal service is independent in local problem solution; organizational and personnel independence. Local administrations have the opportunity to protect the municipality interests judicially.

Objectively, there is joint political and social responsibility increase of state and municipal authorities for population life quality in municipalities. 
Logically, amendments should be made to the RF Constitution of 1993 and the entire array of regulatory legal acts regarding the strengthening of joint responsibility of state and municipal bodies to improve the life quality of Russian citizens.

The principle of responsibility of bodies and officials of local self-government to the population, the state, organizations, individuals and legal entities is one of the most important principles of public authority existence. Responsibility is an inevitable consequence of managerial decisions made by local authorities and officials. Responsibility should also arise in case of inaction or improper actions by the authorities to implement constitutional guarantees and to provide social services to the population.

We can conclude the following: the population judges the work of a large-scale, complex state machine by its lower levels - local administrations.

\section{The introduction of digital technology in municipal management practice}

The needs to improve the population life quality in municipalities determine the development and implementation of new management technologies. Prospects for improving the efficiency and responsibility of municipal authorities are associated with the systematic implementation of digital technologies.

The theory of state and municipal service determines the inclusion of new technology management by state and municipal administration in practice.

The effectiveness of digital technology is determined by the following measures:

- openness and transparency provision for management processes;

- ensure the publicity of activities mandatory for public authorities;

- contribute to real public control.

New digital technologies of the state and municipal government process have two main development vectors:

1) digital technology management process;

2) secondly, digital communication technologies with society and managed objects: with citizens and organizations; with individuals and legal entities.

Digital management process technologies include:

a) the creation of managed object management databases;

b) the creation of a digital platform of best management practices;

c) expert digital technologies for making managerial decisions based on digital analysis of managed objects and the knowledge of best management practices.

Thus, on the basis of managerial process digital technology introduction and the analysis of information about managed facilities, as well as digital communication technologies, it is possible to achieve systemic digitalization of state and municipal government.

The wide dissemination of new digital governance, open and accountable to people, is initiated by the political will of the President V.V. Putin. The experience of the digital Management Center, which was organized by the Government of the Moscow Region, which began to work in 2018 , made it possible to demonstrate the implementation of the new digital management. The new management model is the basis for the digital Management Center activities of the Moscow Region. This model is based on three key principles: "we know everything - we quickly solve it - we do not allow it". At the first stage, a map of the Moscow Region resident problems was created, the points of tension were identified - the most painful and common socio-economic problems of residents. At the second stage, they develop the technologies to inform performers about the existing problems. Contractors are required to solve a problem quickly and efficiently and report on their actions. At the third stage, management decisions are taken to prevent similar problems in the future. The Control Center uses digital technologies to monitor the proper condition of municipalities: courtyards and porches, timely garbage collection, adherence to public transport timetables, access to clinics, kindergartens and schools, etc. 
The main reason for the regional Management Center success is a real solution to the problems - each appeal of the residents causes an adequate managerial response. They require constant control at the highest level over the solution of resident problems by state and municipal employees. The principle of personal responsibility of performers is operated steadily.

The development of the regional Management Center was represented by the creation of municipal control centers in all 64 urban districts (2019). The President of the Russian Federation supported the examples of successful managerial mechanisms for communication between the authorities and the population in Krasnogorsk, Tatarstan, Moscow and other regions. It is necessary to analyze the experience of the best municipalities, project teams and replicate these management decisions throughout the country.

According to public opinion measurements, nowadays, citizens consider active sites of public services as the most useful products of digital technologies.

A significant innovation in the information-servicing field was municipal multifunctional centers of social and economic state and municipal services.

The federal government supports successful digital local management practices and is ready to help economically weak municipalities. Municipalities lack their own information resources and funds, therefore the regional and federal state authorities are called upon to support digitalization at the local level from the budgets of other levels. This will be the implementation of the new constitutional principle of shared responsibility.

Prospects for digital technologies of state and municipal government:

- Firstly, you can get an objective analysis of amendment implementation results to the RF Constitution. Digital technologies give a real picture of new social standards and norms of decent living introduction into the municipality;

- secondly, full and thorough digital control is required over the receipt and expenditure of state and public finances for new social standards. Management targeted control will provide digital technology.

Systemic digitalization of state and municipal government is carried out on the basis of understanding the unity of social goals and the joint responsibility of the public authorities of Russia, using the theory of professional state and municipal services.

\section{Discussion}

\section{Authority responsibility increase for activity results and population life quality}

Local governments and state bodies must fulfill the main task of public authority in citizens' right protection and constitutional guarantee implementation. But in the process of this task accomplishing, they are included in competitive relations. The competition between local and state bodies is objective in nature to some extent, because it is due to the difference of the interests that they are called upon to protect. Local authorities should defend the interests of the municipality population. Government bodies are obliged to protect the state interests and the aggregate interests of the entire Russian society.

Objective contradictions in the interests of local and state bodies are exacerbated by a subjective struggle. This is the struggle for resources. There are the interests of financial and economic groups behind each business project in a municipality. These groups are often important not only when residents need paths in a park and new buildings, but in allocation of funds for these works. Unfortunately, often these funds are distributed not in favor of public interests, but in favor of the selfish interests of specific financial and economic groups.

The functions of local governments are extensive: housing and communal service and public transport provision for the municipality; maintenance of local roads and land management; improvement of settlements, etc. There is an extremely low level of social institutions in remote 
corners of Russia: paramedic-midwife centers, rural schools, and few 'cultural centers'. Municipal authorities are only half provided with financial means to fulfill their powers and obligations.

Based on the amendments to the Constitution of the Russian Federation (1993) regarding the legal status of local self-government, it is necessary to amend the Budget Code of the Russian Federation. A proposal is made for discussion on the principle of per capita financing by local government.

The federal and regional authorities allocate additional financial resources to fulfill the functions of local authorities. The fact that all the money of the municipalities is planned according to target indicators significantly reduces the effectiveness of allocated public fund use. That is, the residents of the settlements can only slightly affect the budgeting of their urgent needs.

The residents know better what they need in the first place to improve the quality of their life in order to live in a comfortable settlement. In the situation of budget target use, launched from above, you need to think not only about sufficiency, but also about the efficiency of financial resource spending.

The scientific community also discusses possible changes in the budget process based on amendments to the RF Constitution of 1993. Introduction of the new principle of "participatory budgeting" into the budget process, using the methodology of public hearings.

Suppose that the funding for municipalities will be significantly greater as the result of constitutional changes and innovations in the budget process. But will they increase effectiveness of local administrations and the quality of population life from large finance obtaining? We need new social criteria for effective spending of financial resources.

The Center for Strategic Studies currently develops the methodology to assess the population life quality in regions and municipalities.

The publications of this article authors contain new scientific approaches to the development of methods for assessing the municipality population life quality. The new methodology for assessing the population life quality of the regions and municipalities of Russia should be based on two fundamental principles: firstly, citizen equal access provision to constitutional social guarantees and social services, regardless of place of residence; secondly, high standards for main social sphere provision - health care and education.

The effectiveness of government bodies and municipal servants directly depends on the personal responsibility of officials.

The responsibility of local authorities and officials to the state is one of responsibility types. The main responsibility of bodies and officials of local self-government is responsibility to the population, to each person.

The Working Group on Amending the Constitution of the Russian Federation of 1993 should fix the high level of responsibility of bodies and officials of all levels of public authority to implement new social guarantees and standards of the RF Constitution, new indicators and methods for assessing the population life quality.

\section{Problems of municipal government systemic digitalization}

Systemic digitalization is a complex management process that causes a lot of conflicting assessments and requires extensive scientific discussion.

Citizens and public organizations are ambivalent about the processes of digitalization of state and municipal government.

Any process taking place in society has positive and negative consequences. This is the fundamental law of dialectics. From the standpoint of the theory of social management, it is 
important to analyze the whole complex of consequences, model scenarios of society development, and weigh the positive and negative aspects of systemic digitalization of society.

The risks of process digitalization are studied by scientists and managers. These risks are diverse, they are both internal and external in nature. These are political, economic, social, technical risks and others.

The analysis of digital technology introduction on the example of the activities of banks and governing bodies revealed the danger of a technical ascept - the malfunctions in the operation of maintenance equipment and the loss of accumulated data on citizens and organizations.

Corruption risks during digital technology introduction are caused by the threats of mercenary use of databases of state and municipal government bodies. These are the risks of selling information about citizens to criminals using state and municipal services.

Some social groups have a prejudice about the total control of the state over a person with the help of digital technologies. This postulate is especially cultivated among the adherents of liberal ideology and sectarian communities.

Social management should create the conditions for the implementation of resident interests using digital technologies. On the other hand, it is necessary to foresee negative phenomena and level them. This can be facilitated by the extensive advertising, informational and explanatory work of state and municipal employees to promote the positive aspects of digital state and municipal service provision to citizens and organizations. In this case, it is necessary to comply with the principle of voluntariness of digital data processing concerning individuals and legal entities.

The dangers of excessive or dishonest digitalization of state and municipal government must be countered in a normative manner, prohibiting excessive digital control over the life and work of citizens.

In the context of systemic digitalization of state and municipal government, the risks of the public and public field digitalization are growing and the role of information protection is adequately strengthened: first of all, for citizens and the whole society; secondly, for the public authorities themselves, both state and municipal ones.

State and municipal government quality improvement based on digital technologies leads to the emergence of new risks for citizens, organizations, and governing bodies. Therefore, it is necessary to create a new Ethics and regulatory framework for digital management, new ethical and regulatory principles for the use of digital technologies in state and municipal government.

\section{Summary}

Modern global and internal threats to the life of Russian citizens multiply the responsibility increase of public authorities at all levels for managerial decisions and performance.

It is necessary to solve the tasks of protection from external dangers of all kinds, from the military, financial, economic, cultural threat, to threats to the life and health of the Russian population. Internal threats to social and economic development are greatly exacerbated by the inequality of opportunities for citizens, municipalities and entire regions to exercise constitutional rights and receive social services.

Rising threats require a new methodology for managerial socio-economic problem solution. Faced by global and internal threats, scientists are building a new paradigm of social management. A special part of this paradigm of social management is the theory of state and municipal service.

The theory of state and municipal service is formed as the knowledge of socially oriented professional managerial activities of employees in the bodies of a single public authority. This theory considers governing bodies at all levels as a socially responsible and economically effective public law institution. 
The weak link in the current situation of socio-economic development of Russia is the municipal level. The municipal service is the managerial core of local self-government and the quality of life in the municipality directly depends on the effectiveness of its activities.

The new legal framework for socially oriented activities of local authorities is determined by the amendments to the Constitution of the Russian Federation. The purpose of these changes is to increase the coordination of activities and the responsibility of all levels of the unified public authority (federal, regional, municipal) for the implementation of constitutional rights and guarantees, for compliance with modern social standards in the most remote, most economically weak municipalities of Russia.

Digital technologies can significantly increase the level of managerial competence among municipal employees and the quality of management in municipal administration. On the basis of objective digital analysis and digitalization of management processes, it is possible to ensure socially oriented and cost-effective development of each municipality.

The scientific substantiation of state and municipal manager activities in the form of state and municipal service theory determines the widespread introduction of digital technologies in the practice of analysis and subsequent solution of municipality resident problems. This methodology of management activities must be actively used in the practical activities of managers, and in the training of employees.

The authors believe that the prospects for further research on the activities of local authorities are connected with the new paradigm of socially responsible and economically effective management based on constitutional amendments, strengthening a unified public authority, and systemic digitalization of governance.

Researchers of management at the municipal level have not yet been able to introduce socially-oriented management technologies and new indicators of managerial performance into practice widely. Thus, the population critically evaluates the activities of public authorities, noting their low social efficiency and insufficient responsibility of bodies and officials for the results of their work. Therefore, the trends of further research are related to further scientific search for the answers to social needs in socially effective management, evoking the trust and respect of citizens.

\section{References}

Cao, Q. (2014). Discourse, politics and media in contemporary China.

Cuadrado-Ballesteros, B., Sánchez, I., \& Martínez-Ferrero, J. (2020). Commercialization of Local Public Services. Doi:10.4018/978-1-5225-9860-2.ch090.

Eberhardt, C. (2015). Discourse on climate change in China: A public sphere without the public. China Information, 29, 33-59. Doi: 10.1177/0920203X15571261.

Edelman Trust Barometr. (2019). Global Report.

URL:https://www.edelman.com/sites/g/files/aatuss191/files/201902/2019_Edelman_Trust_Barometer_Global_Report.pdf

Hughes, P. (2019). Public Service Legislation and Public Service Reform. Policy Quarterly, P.15. Doi:10.26686/pq.v15i4.5918.

Ivanov, V.N. (1996). Social Technologies in the Modern World. Moscow: Slavjanskii dialog.

Kalinichenko, L.A. (1998). Municipal Service Organization. Saratov: Sarat. Un-ta.

Kalinichenko, L.A.(2001). Social organization of public service. - M.: The Russian Academy of Public Service under the President of the Russian Federation.

Kalinichenko, L.A., \& Adamskaya, L.V. (2018). Local Administration - Moscow: Prometheus, 2018.

Man, J., \& Rosentraub, M. (1998). Tax Increment Financing: Municipal Adoption and Effects On Property Value Growth. Public Finance Review, 26, 523-547. Doi:10.1177/109114219802600601.

Ngan, N., Bui, H. \& Khoi, B. (2020). Public Service Quality In Vietnam, 29,1067-1072. 
Nukpezah, J.A. (2019). L Local Governments and the Property Tax in the USA. Doi:10.1007/9783-319-31816-5_3874-1.

Obasa, Dr. (2019). Public Service Reform. The International Journal of Humanities \& Social Studies, 7. Doi: 10.24940/heijhss/2019/v7/i11/HS1910-004.

Stockmann, D., (Danie) \& Esarey, A., \& Zhang, J. (2011). Advertising Chinese Politics: The Effects of Public Service Announcements in Urban China. SSRN Electronic Journal. Doi:10.2139/ssrn.1673073.

Urzha, O. (2019). The Development of Socio-Economic Relations at the Municipal Level in Modern Russia: Problems and Solution Approaches. Amazonia Investiga, 8(20), 300-309.

Urzha, O., Kataeva, V., \& Evstratova, T. (2018). Sociology of governance as a methodology for developing scenarios for simulation case studies in the governance training system. International Scientific Conference on Economic and Social Development, 627-636.

Urzha, O.A., Kataeva, V.I., Evstratova, T.A., Zhukova, V., \& Ilina, I.Yu. (2018). Using The Scenarios Of Simulation Case Assignments In The Educational Process Of Students In The Specialty «State and Municipal Management», Master's Degree Programme. International Journal of Engineering and Technology (UAE), 7, 4(38), 597-602.

WCIOM. National Unity: A Dream or Reality? 2019. URL:https://wciom.ru/index.php?id=236\&uid=9978 